\title{
De twitterende wijkagent en het veiligheidsgevoel van de burger
}

\author{
Imke Smulders, Wilbert Spooren \& Emile Kolthoff
}

In dit artikel wordt gerapporteerd over een conceptueel model dat de relatie tussen twittergebruik door de wijkagent en de veiligheidsbeleving van de burger in beeld brengt. Het model is getoetst aan de hand van een relatief grootschalig surveyonderzoek. De resultaten ondersteunen het model en laten ook een kleine invloed van twittergebruik op veiligheidsgevoelens en het oordeel over de politie zien. Grootschaliger onderzoek is nodig om de resultaten te bevestigen en een meer experimentele opzet is gewenst om de positieve en negatieve effecten van Twitter nauwkeuriger in kaart te brengen.

\section{$1 \quad$ Inleiding}

Sociale media bieden nieuwe, laagdrempelige manieren om in contact te komen en blijven met grote groepen mensen. Sommige sociale media zijn er met name op gericht een netwerk van vrienden (Facebook) of professionele relaties (LinkedIn) op te bouwen en te onderhouden, andere zijn vooral gericht op het delen van informatie, zowel zakelijk als privé (Twitter).

Verschillende politiekorpsen hebben ervoor gekozen Twitter in te zetten als extra instrument voor - met name - de wijkagent om in contact te treden met de burger. De politieorganisatie heeft hiervoor een aantal doelen geformuleerd: het uitbreiden van de interactie met de burger, het vergroten van de bekendheid van - en daarmee ook het begrip voor - politiewerk en het verbeteren van het imago van de politie (Unit Communicatie, Politie Midden- en West-Brabant). Er zijn echter ook andere doelen denkbaar, zoals het vergroten van de zelfredzaamheid van de burger, het beïnvloeden van de gepercipieerde leefbaarheid in de wijk, het vergroten van de objectieve veiligheid (bijvoorbeeld via verhoogde alertheid bij burgers, verhoogde communicatiebereidheid bij burgers of een nauwere samenwerking tussen burgers en politie) en het beïnvloeden van de veiligheidsbeleving. In dit artikel wordt verslag gedaan van een onderdeel van een breder onderzoeksproject naar de relatie tussen structurele externe communicatie door wijkagenten via Twitter en de veiligheidsbeleving van burgers.

\subsection{Veiligheid en veiligheidsbeleving}

Opvallend is dat de perceptie van (sociale) onveiligheid - de veiligheidsbeleving van burgers in de samenleving - vaak niet gelijk oploopt met de daadwerkelijke, objectieve veiligheid zoals bijvoorbeeld weergegeven in de Gemeentelijke Veiligheidsindex (zie bijvoorbeeld de Veiligheidsindex Rotterdam, Directie Veiligheid 2012). Uit onderzoek blijkt dat een verbetering van de objectieve veiligheid er 
niet automatisch toe leidt dat burgers zich ook daadwerkelijk veiliger gaan voelen (Elffers en De Jong 2004), al is dat wel een van de aannames in de Gemeentelijke Veiligheidsindex. Er zijn blijkbaar andere factoren die een rol spelen in de veiligheidsbeleving van de burger.

Vanderveen (2006) stelt dat het concept fear of crime een complex fenomeen is, waarvan we nog geen adequaat totaalbeeld hebben; we weten nog niet precies uit hoeveel en welke onderdelen het bestaat en hoe deze zich tot elkaar verhouden. Wel is duidelijk geworden dat het geïsoleerd bekijken van de verschillende onderdelen niet toereikend is om tot een correct en volledig beeld te komen. Spithoven (2010: 23) komt in zijn onderzoek naar overeenkomsten en verschillen in de beleving van sociale onveiligheid in navolging van Van Noije en Wittebrood (2010) en Oppelaar en Wittebrood (2006) tot een theoretisch model waarin wordt weergegeven hoe verschillende factoren uit de sociaal-culturele, situationele en individuele context van invloed zijn op de risicoperceptie ten aanzien van sociale onveiligheid. Hoewel ons onderzoek zich richt op veiligheidsbeleving, zijn er duidelijke paralellen waar te nemen met het model van Spithoven. Die risicoperceptie gaat volgens verschillende auteurs (Ferraro 1995; Ferraro en LaGrange 1987; Warr 2000; Wilcox Rountree en Land 1996) vooraf aan angstgevoelens met betrekking tot sociale onveiligheid. Boers, Van Steden en Boutellier (2008) noemen criminaliteit en overlast, slachtofferervaring en verloedering als factoren die een negatieve invloed uitoefenen op veiligheidsbeleving en Maas-de Waal (2002) wijst op de relatie tussen het bevolkingsaandeel met een lage sociaaleconomische status in een wijk en onveiligheidsbeleving. Ook de ontbinding van het sociale leven als gevolg van veranderingen in de samenleving (Elffers en Jong 2004; De Hart 2002; Terpstra 2004) en de rol van de media (Elchardus, Groof en Smits 2005; Elffers en Jong 2004) horen thuis in het rijtje negatief beïnvloedende factoren.

Er is ook onderzoek gedaan naar factoren die een positieve invloed uitoefenen op de veiligheidsbeleving van burgers. In dit kader komen de volgende factoren vaak aan de orde: sociale cohesie (De Hart 2002; Sampson en Raudenbush 1999), zelfredzaamheid, leefbaarheid en vertrouwen in de buurt (Boers et al. 2008), sociaal kapitaal en maatschappelijke stabiliteit (De Hart 2002; Van Wilsem 1997) en institutioneel en maatschappelijk vertrouwen (Elchardus et al. 2005). Blokland (2009) wijst op het belang van sociale controle ten aanzien van veiligheidsbeleving, waarbij zij de stelling van Newman (1973) aanhaalt dat voldoende capaciteit aan sociale controle in een omgeving tot een positieve spiraal met betrekking tot veiligheid kan leiden.

Externe communicatie door relevante partijen uit de veiligheidsketen, zoals politie, justitie, gemeente en welzijnsinstellingen, ontbreekt in het rijtje van veelgenoemde en onderzochte factoren. Wanneer communicatie aan de orde komt in onderzoeken naar veiligheid en veiligheidsbeleving, gaat het met name om incidentele, directe contacten tussen burgers en politie, zoals aangiftes en bekeuringen. Er wordt dan vooral een verband gelegd met het oordeel van burgers over de politie, niet zozeer met veiligheidsbeleving. Naast deze incidentele, directe interacties treedt de politie ook op een meer structurele manier in contact met burgers, bijvoorbeeld via haar website, nieuwsbrief, aankondigingen in lokale week- 
bladen en bij aanvang van het hier besproken onderzoek ook op pilotbasis via sociale media zoals Twitter en Facebook.

\section{Het onderzoek}

Gelet op de hiaten in het hiervoor beschreven onderzoek wat betreft de relatie tussen communicatie en veiligheidsbeleving, is onderhavig onderzoek gericht op het in kaart brengen van verschillende aspecten van die relatie. Daarbij staat het gebruik van Twitter door wijkagenten centraal. Gezien de beperkte ervaringen met het gebruik van Twitter door wijkagenten en de weinige literatuur over eventuele effecten van communicatie op veiligheidsbeleving, was het bij aanvang van het onderzoek niet mogelijk om gefundeerd expliciete verwachtingen te formuleren. Er is dus bewust gekozen voor een neutrale formulering van de centrale onderzoeksvraag:

'Wat is de relatie tussen het gebruik van Twitter door wijkagenten en de veiligheidsbeleving van burgers?'

Om deze vraag te beantwoorden zijn eerst alle relevante relaties die bekend zijn uit de literatuur in een theoretisch model gevat. Vervolgens is door middel van surveyonderzoek gepoogd inzicht te krijgen in de relaties zoals die zich in de empirie voordoen.

\section{Introductie conceptueel model}

Van verschillende determinanten van veiligheidsbeleving kan worden verwacht dat deze op een of andere manier samenhangen met het twittergebruik van de wijkagent, bijvoorbeeld doordat de wijkagent er met zijn tweets invloed op uitoefent, zoals op de perceptie van de leefbaarheid in de buurt, of doordat het twittergebruik van de wijkagent bijdraagt aan een verbetering van bepaalde omstandigheden, zoals de objectieve veiligheid. In deze paragraaf worden deze - voor het huidige onderzoek relevante - determinanten uiteengezet, waarna een conceptueel model wordt geïntroduceerd dat de relaties tussen de besproken determinanten, veiligheidsbeleving en het twittergebruik van de wijkagent, weergeeft.

Objectieve veiligheid in de buurt (en dan vooral de inschatting daarvan) neemt uiteraard een belangrijke plaats in. We weten dat objectieve veiligheid en veiligheidsbeleving niet een-op-een causaal samenhangen, maar de objectieve veiligheid is wel een factor in de veiligheidsbeleving van de burger. Dat is bijvoorbeeld te zien in het crime-causes-fear-model (Harris 1969; Skogan en Klecka 1977), dat Vanderveen (2006) bespreekt in haar overzicht van theoretische modellen voor de oorzaken van angst voor criminaliteit. Verschillende auteurs betogen overigens dat overlast en verloedering een grotere invloed hebben op onveiligheidsbeleving dan criminaliteit, bijvoorbeeld doordat deze worden gezien als een symbool voor een verhoogde kans op slachtofferschap (Hunter 1978). Mensen maken 
gebruik van signalen uit de fysieke omgeving om de sociale controle door anderen in te schatten (Blokland 2009; Newman 1995). Schoon geeft het signaal 'er geeft iemand om mijn leefomgeving en dus om mij' , vuil geeft het signaal dat het niemand wat kan schelen en dat je dus ook van anderen niets hoeft te verwachten (wantrouwen) of dat je er niet van uit kunt gaan (mistrust, zie Sztompka 1999). De continue aanwezigheid van incivilities geeft daarnaast het signaal dat de verantwoordelijke instanties niet met dit probleem kunnen omgaan (Taylor en Hale 1986). De inschatting van de objectieve veiligheid kan dus rechtstreeks van invloed zijn op ervaren onveiligheidsgevoelens, maar ook via risicoperceptie.

Risicoperceptie wordt in de literatuur veelvuldig genoemd als intermediërende factor voor onveiligheidsgevoelens. Verschillende auteurs stellen dat risicoperceptie causaal voorafgaat aan angstgevoelens; signalen uit de omgeving worden via een cognitief verwerkingsproces vertaald naar een risico-inschatting om slachtoffer te worden van criminaliteit en deze inschatting resulteert in een bepaalde angst voor criminaliteit (Ferraro 1995; Ferraro en LaGrange 1987; Oppelaar en Wittebrood 2006; Warr 2000; Wilcox Rountree en Land 1996). Ook in het conceptueel model van Boers et al. (2008) is risicoperceptie opgenomen als intermediërende factor voor de invloed van positieve en negatieve factoren op de veiligheidsbeleving. Analyses wijzen uit dat risicoperceptie intervenieert met criminaliteit en overlast, slachtofferervaring, leefbaarheid en zelfredzaamheid. De laatste factor heeft zelfs alleen via risicoperceptie effect op de veiligheidsbeleving.

Sociaal kapitaal verwijst naar de relaties tussen mensen (vrienden, buren, vreemden), sociale netwerken en de wederkerige normen en het vertrouwen in anderen die eruit voortvloeien (Putnam 2000). Het heeft betrekking op het sociale gehalte en het coöperatief vermogen van groepen. Sociaal kapitaal is instrumenteel: het vergemakkelijkt het gecoördineerde gezamenlijke handelen om problemen op te lossen waarvoor men zich gesteld ziet en daarmee het efficiënt functioneren van een gemeenschap of politiek systeem. Waar wijken beschikken over veel sociaal kapitaal 'public spaces are cleaner, people are friendlier and the streets are safer', aldus Putnams bondige samenvatting van onderzoek dat is gedaan naar de relatie tussen aspecten van sociale cohesie, leefbaarheid en veiligheid (Putnam 2000, 307). Er zijn verschillende onderzoeken die een positief verband laten zien tussen sociale cohesie en veiligheidsbeleving, zoals het SCP-rapport over sociaal kapitaal op het platteland (Sociaal en Cultureel Planbureau 2008). Daarin wordt geconcludeerd dat sociale samenhang tussen buren de leefbaarheid bevordert.

Oordeel over de politie. Er is empirisch bewijs dat de politie een belangrijke rol heeft in het verlichten van onveiligheidsgevoelens en angst voor criminaliteit; de meningen verschillen echter over hoe die rol zou moeten worden ingevuld (Hale 1996). Moet de politie zich uitsluitend richten op het bestrijden van criminaliteit met als bijwerking een vermindering van onveiligheidsgevoelens (aangenomen dat die bijwerking dan optreedt) of moet zij ook rechtstreeks actie ondernemen om die gevoelens van onveiligheid te verminderen? Alleen al de aanwezigheid van de politie op straat ('meer blauw op straat') zou afdoende kunnen zijn om angstgevoelens te verminderen door symbolische geruststelling (Bahn 1974). Beroepsma- 


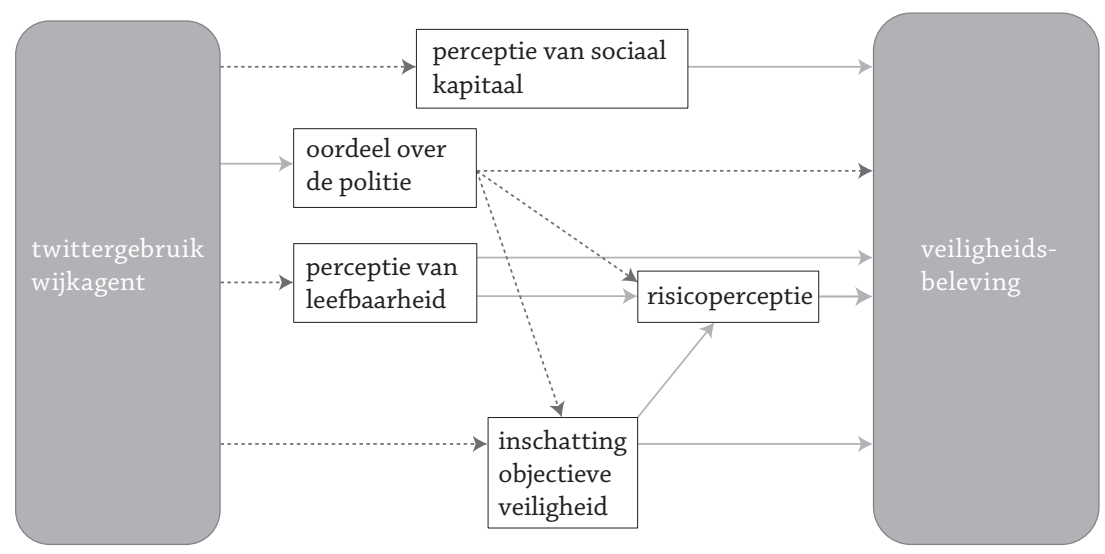

Figuur 1 Conceptueel model veiligheidsbeleving, determinanten en onderlinge relaties

tige aanwezigheid van geüniformeerde overheidsmedewerkers met duidelijke lokale binding vermindert angstgevoelens (Balkin en Houlden 1983), doordat dit mensen het gevoel geeft dat criminaliteit beheersbaar en voorspelbaar is. Vanuit een psychologisch perspectief vermindert dit angst (Winkel 1986). Evaluatie van community policing-programma's in onder andere New Jersey (Pate, Wycoff, Skogan en Sherman 1986; Williams en Pate 1987), Michigan (Trojanowicz 1986) en Melbourne (Brown 1980) laat zien dat meer politiesurveillance te voet een positief effect heeft op de veiligheidsbeleving, de perceptie van criminaliteit als probleem en vertrouwen in de politie. Dat laatste is ook een belangrijke factor in de verklaring van angst voor criminaliteit (Box, Hale en Andrews 1988).

Het ontwikkelde conceptueel model (zie figuur 1) geeft verschillende relaties weer: uit de literatuur bekende relaties tussen veiligheidsbeleving en determinanten daarvan en relaties tussen verschillende determinanten van veiligheidsbeleving onderling (weergegeven met ononderbroken pijlen). Bovendien expliciteert het model de mogelijke relaties tussen het twittergebruik van de wijkagent en de veiligheidsbeleving van de burger die te verwachten zijn op basis van literatuur en de huidige onderzoeksopzet, zowel rechtstreeks als via verschillende determinanten van veiligheidsbeleving (weergegeven met gestippelde pijlen). Voor de volledigheid dient vermeld te worden dat dit conceptueel model geen uitputtend overzicht biedt van de determinanten van veiligheidsbeleving; alleen de determinanten waarvan een gefundeerde verwachting bestaat dat deze een samenhang vertonen met het twittergebruik van de wijkagent, zijn opgenomen in het model.

\subsection{Verwachtingen twittergebruik}

Verschillende onderzoeken naar community policing en gebruik van sociale media geven aanleiding om te denken dat het gebruik van Twitter door de wijkagent samen zou kunnen hangen met de besproken factoren. Brits onderzoek naar de 
effecten van informatievoorziening op percepties van de buurt en percepties van de lokale politie (Quinton 2011) laat positieve effecten zien. Burgers ontvingen gedurende een bepaalde periode 'crime maps' van hun eigen omgeving en politieinformatie van hun lokale korps. De politie-informatie bestond uit informatie over bereikbaarheid van het korps en individuele agenten, maar ook informatie over speerpunten en acties in de omgeving. Deze interventie zorgde voor positieve effecten op de perceptie van het functioneren van de politie: burgers dachten meer (dan de controlegroep die geen informatie ontving) dat de politie weet wat er speelt en zich bezighoudt met de dingen die ertoe doen. Burgers schatten het risico om zelf slachtoffer te worden iets hoger in. Dit leidde echter niet tot een groter gevoel van onveiligheid. Het idee dat mensen zich onveiliger gaan voelen wanneer zij meer informatie krijgen, werd in dit onderzoek dus weerlegd. Dit onderzoek betrof informatievoorziening via websites. Het huidige onderzoek wijst uit of informatievoorziening via Twitter dezelfde effecten sorteert.

Aangezien de inzet van sociale media door de politie nog relatief nieuw is, is er nog niet veel grondig onderzoek verricht naar de effecten. Een Britse studie naar het gebruik van Twitter door politieagenten (Crump 2011) laat zien dat Twitter, ondanks de ambities van de politie om het medium in te zetten om interactie met en betrokkenheid van de burger te stimuleren, vooral effectief wordt gebruikt als extra kanaal om burgers van informatie te voorzien. Dit geldt met name bij incidenten; daar blijkt Twitter zeer effectief bij het informeren en organiseren van grote groepen mensen.

Voorlopige evaluaties in Nederland zijn positief (Cornelissens en Ferwerda 2010). Systematisch onderzoek is gedaan naar Burgernet (Meijer, Grimmelikhuijsen, Bos en Fictorie 2011; Van der Vijver et al. 2009) en SMS-alert (politie Midden- en West-Brabant 2009); Twitter is samen met YouTube onder de loep genomen door Meijer, Grimmelikhuijsen, Fictorie, Thaens en Siep (2013) in hun algemene onderzoek naar gebruik van sociale media door de politie. Zij concluderen dat Twitter een bijdrage levert aan de coproductie ${ }^{1}$ van veiligheid: zowel de coproductie van opsporing als de coproductie van community policing wordt versterkt. Deze coproductie leidt tot positieve effecten op de percepties van burgers, met name op het oordeel over de legitimiteit van de politie. Op veiligheidsgevoelens vonden zij geen effect: burgers voelden zich niet veiliger, maar ook niet onveiliger. Veltman, Junger en Johannink (2012) vonden (met enig voorbehoud) in hun onderzoek onder volgers van Groningse wijkagenten positieve effecten op beeldvorming van de politie en op meldingsbereidheid en geen effecten op veiligheidsbeleving.

Roodenburg en Boutellier (2014) stellen in hun onderzoek naar de wijze waarop het gebruik van Twitter door de wijkagent kan bijdragen aan vertrouwen in de

1 Meijer et al definiëren de coproductie van veiligheid als het gezamenlijk creëren van meer veiligheid door de interacties tussen burgers en politie te versterken. Zij merken daarbij op dat coproductie in de Nederlandstalige literatuur vaak gelijk wordt gesteld aan participatie en dan het betrekken van burgers bij de beleidsontwikkeling betreft. De Engelstalige literatuur over coproductie gaat echter veeleer over het betrekken van burgers bij de beleidsuitvoering en daarmee is deze literatuur relevanter voor het bestuderen van gebruik van Twitter door de politie (Ostrom, 1978; Ostrom, 1996; Alford, 2009). 
politie dat uit - met name Amerikaans en Engels - onderzoek is gebleken dat vertrouwen in de politie niet primair bepaald wordt door de effectiviteit van het politieoptreden (performance-based justice), maar dat acceptatie en vertrouwen vooral te maken hebben met de manier waarop de politie optreedt en de bejegening van de burger (procedural justice). Zij onderzoeken het effect van twittergebruik door de wijkagent op vertrouwen in de politie als complex concept aan de hand van het model van Jackson en Bradford (2010). In het conceptuele model dat in dit artikel wordt geïntroduceerd en getoetst, geldt vertrouwen in de politie als onderdeel van het concept 'oordeel over de politie', dat is opgenomen als een van de relevante determinanten van veiligheidsbeleving.

Wanneer we kijken naar het theoretisch kader van het huidige onderzoek, dienen zich verschillende suggesties aan voor de manier waarop de twitterende wijkagent invloed uit zou kunnen oefenen op de veiligheidsbeleving van de burger. Wanneer het twittergebruik van de wijkagent leidt tot een coproductie van veiligheid, bijvoorbeeld via een verhoogde communicatie- en aangiftebereidheid met een verhoogde ophelderingsgraad tot gevolg, zal dat ook positief uitpakken voor de beleving van veiligheid.

Een grotere objectieve veiligheid zorgt niet een-op-een voor een evenredige mate van subjectieve veiligheid, maar het is wel een factor van invloed. Gezien de functie van Twitter als online instrument voor community policing, kan ook via die route positieve invloed op veiligheidsgevoelens ontstaan: een toename in de coproductie van community policing kan zorgen voor een verbetering van zowel de objectieve als subjectieve veiligheid en voor een positievere beeldvorming van de politie, wat ook weer bijdraagt aan gevoelens van veiligheid. Ook de veronderstelling dat het signaal dat wordt afgegeven door incivilities zorgt voor gevoelens van onveiligheid - 'het kan niemand wat schelen dus ik hoef niets van anderen te verwachten' en 'de verantwoordelijke instanties kunnen niet met dit probleem omgaan' - kan worden weersproken door de twitterende wijkagent; alleen al het feit dat hij er in zijn tweets aandacht aan besteedt, laat zien dat het wel iemand kan schelen en dat de verantwoordelijke instanties zich ermee bezighouden. Ook kan de wijkagent via deze weg bijdragen aan het oplossen van incivilities. Inzet van Twitter om een reëler beeld te geven van de mate waarin incivilities voorkomen, kan zorgen voor een positievere/adequatere inschatting van de objectieve veiligheid in de buurt.

Ook via invloed op risicoperceptie en op de perceptie van sociaal kapitaal en leefbaarheid kan het gebruik van Twitter door de wijkagent invloed hebben op veiligheidsbeleving. Deze factoren kunnen positief beïnvloed worden door het twittergebruik van de wijkagent, via onder andere informatievoorziening, preventietips en adviezen. Informatie over wat er speelt in de wijk kan bijvoorbeeld zorgen voor een reëlere perceptie van risico's, leefbaarheid en sociaal kapitaal. Ook tips en adviezen over preventieve maatregelen die mensen zelf kunnen nemen, kunnen bijvoorbeeld bijdragen aan een reëlere risicoperceptie. 


\section{Methode}

Om het effect van het gebruik van Twitter door de wijkagent op de veiligheidsbeleving van burgers te meten, is op twee momenten aan burgers in het onderzoeksgebied - bestaande uit de wijken waarin de betrokken wijkagenten actief zijn gevraagd een vragenlijst in te vullen. Het eerste meetmoment vond plaats op het moment dat de wijkagenten in het onderzoek startten met het gebruik van Twitter, dus nog voordat de respondenten de wijkagenten enige tijd hadden kunnen volgen. Dit moment viel in maart 2012. Het tweede meetmoment vond ruim zeven maanden na het eerste meetmoment plaats, in oktober 2012, zodat de respondenten die een wijkagent volgden op Twitter dat inmiddels geruime tijd hadden gedaan.

\subsection{Vragenlijst 'Politie en Veiligheid in uw buurt'}

Het meten van veiligheidsbeleving is een lastige zaak en aan nagenoeg alle meetmethoden kleven nadelen (Pleysier en Vanderveen 2012). Om een compleet beeld te krijgen en een gefundeerd antwoord te kunnen geven op de vraag of het getwitter van de wijkagent samenhangt met de veiligheidsbeleving van burgers, is in het onderzoek gekozen voor een combinatie van methoden. Ook binnen de vragenlijst als meetinstrument is gekozen voor verschillende invalshoeken en maatstaven, om mogelijke vertekening door de gebruikte meetmethode te ondervangen. In deze paragraaf worden de opzet en inhoud van de vragenlijst uiteengezet en verantwoord.

De meeste onderdelen van de vragenlijst zijn gebaseerd op de Veiligheidsmonitor (Centraal Bureau voor de Statistiek 2013), die jaarlijks wordt afgenomen op landelijk, regionaal en (beneden)lokaal niveau. Dit gevalideerde instrument bevat verschillende onderdelen die ook in het huidige onderzoek van belang zijn, daarom zijn verschillende vragen uit de Veiligheidsmonitor gebruikt in de vragenlijst 'Politie en Veiligheid in uw buurt'. Deze vragenlijst bestaat uit acht onderdelen en start met een korte introductie. Deze introductie bevat een korte uitleg van onderwerp en doel van de vragenlijst en een instructie voor het beantwoorden van de vragen en het terugsturen van de vragenlijst. Uiteraard zijn participanten er in de introductie op gewezen dat hun antwoorden anoniem worden verwerkt en niet voor commerciële doeleinden worden gebruikt. De vragenlijsten van beide metingen zijn grotendeels hetzelfde. Het verschil tussen de metingen bestaat met name uit de vragen over het volgen van de wijkagent, aangezien deze vragen alleen in de tweede meting relevant waren om aan respondenten voor te leggen. In deze paragraaf wordt van elk onderdeel van de vragenlijst uiteengezet en verantwoord hoe dit tot stand is gekomen.

\section{- Deel 1 en 2: Leefbaarheid}

De eerste twee delen van de vragenlijst gaan over Leefbaarheid en Beleving buurtproblemen en bevragen verschillende aspecten van leefbaarheid, in navolging van de Veiligheidsmonitor. Omdat leefbaarheid een nauwe samenhang vertoont met veiligheidsbeleving, heeft dit concept een vrij prominente plaats in de vragenlijst. In deel 1 Leefbaarheid zijn aan de respondenten elf uitspraken over de buurt voor- 
Tabel 1 Schaalscores leefbaarheid en buurtproblemen (gebaseerd op items uit de Veiligheidsmonitor): samenstelling en betrouwbaarheid $(\alpha)$

\begin{tabular}{lll}
\hline Schaalscore & Samenstelling & Cronbach's $\alpha$ \\
sociale cohesie & leefbaarheid, items 6,7,8,9 & .83 \\
sociale overlast & buurtproblemen, items 6,7,8,14 & .82 \\
fysieke voorzieningen & leefbaarheid, items I,2,3,4,5 & .71 \\
fysieke verloedering & buurtproblemen, items 5,9,10,11 & .71 \\
overlast vermogensdelicten & buurtproblemen, items I,2,3,12 & .80 \\
verkeersoverlast & buurtproblemen, items I7,18,20,21 & .80 \\
overige overlast & buurtproblemen, items 7,15,19,22,23 & .69 \\
\hline
\end{tabular}

gelegd, waarbij zij op een vijfpuntsschaal konden markeren in hoeverre zij het daarmee eens of oneens zijn. De scores op deze afzonderlijke uitspraken zijn gebruikt om tot twee verschillende samengestelde schaalscores met betrekking tot leefbaarheid te komen: de schaalscore sociale cohesie (Cronbach's $\alpha=.83$ ), die geldt als operationalisering van de variabele sociaal kapitaal, en de schaalscore fysieke voorzieningen (Cronbach's $\alpha=.71$ ). In tabel 1 wordt van elke schaalscore weergegeven uit welke uitspraken uit de vragenlijst (items) deze is samengesteld. Vervolgens is aan de respondenten gevraagd rapportcijfers (op een schaal van 1 tot en met 10) te geven voor hun woonomgeving, de leefbaarheid in hun buurt en de veiligheid in hun buurt. Er is gekozen voor de vraag naar een rapportcijfer, omdat hier wordt gevraagd naar beoordelingen van complexe, vage begrippen. Met een rapportcijfer kan een respondent daar een intuïtieve typering aan geven, waarmee deze dicht bij de beleving van de respondenten blijft (Blokland 2009); zij worden immers niet gedwongen hun gevoel in - al dan niet zelf geformuleerde verbale typeringen te wringen die wellicht niet helemaal passend zijn.

In deel 2 Beleving buurtproblemen is de respondenten gevraagd van 25 vervelende voorvallen/misdrijven op een vijfpuntsschaal te markeren hoe vaak deze voorkomen in hun eigen buurt. Vervolgens is gevraagd welke twee problemen die in de buurt voorkomen volgens de respondent het belangrijkste zijn. De scores van de afzonderlijke buurtproblemen zijn - net als de scores van de afzonderlijke items met betrekking tot leefbaarheid in deel 1 - gebruikt om tot samengestelde schaalscores van verschillende aspecten van leefbaarheid te komen en weergegeven in tabel 1 met hun respectievelijke Cronbach's alfa-scores. Alle schaalscores hebben een voldoende hoge betrouwbaarheid: alle Cronbach's $\alpha \geq$.69. Op basis hiervan zijn nieuwe samengestelde scores berekend, gebaseerd op het gemiddelde van de samenstellende schalen.

\section{- $\quad$ Deel 3: Veiligheidsbeleving}

Het belangrijkste concept in de vragenlijst, veiligheidsbeleving, is net als in de Veiligheidsmonitor op verschillende manieren bevraagd: er is zowel gebruikgemaakt van cognitieve als affectieve en gedragsmatige maatstaven (Fattah en 
Sacco 1989; Garofalo 1981). De affectieve component komt terug in de globale vragen naar veiligheidsgevoelens: 'Voelt $\mathrm{u}$ zich wel eens onveilig (in uw eigen buurt)?' en 'Voelt u zich vaak, soms of zelden onveilig (in uw eigen buurt)?' Een voorbeeld van gebruik van een cognitieve maatstaf is de vraag naar risicoperceptie omtrent verschillende vormen van criminaliteit: 'Hoe groot denkt $u$ dat de kans is dat $\mathrm{u}$ het komende jaar zelf slachtoffer wordt van inbraak in uw woning/ mishandeling/diefstal van uw portemonnee?' Aangezien risicoperceptie wordt aangemerkt als een zeer belangrijke (mediërende) factor in veiligheidsbeleving, was het van belang deze in kaart te brengen. Om het gedrag van respondenten (als signaal voor hun attitudes) in kaart te brengen, is er verderop in de vragenlijst gevraagd naar acties als het volgen van de wijkagent op Twitter en aangifteen meldgedrag.

\section{- Deel 4: Oordeel over het functioneren van de politie}

Aangezien uit de literatuur blijkt dat de politie een belangrijke rol heeft in het verlichten van onveiligheidsgevoelens en angst voor criminaliteit, is er in de vragenlijst in het huidige onderzoek, in navolging van de Veiligheidsmonitor, gevraagd naar het oordeel dat mensen hebben over het functioneren van de politie. Ook in dit onderdeel is - in navolging van de Veiligheidsmonitor - de respondenten eerst gevraagd naar een intuïtieve beoordeling van het totale functioneren van de politie in hun buurt. Vervolgens is hier specifieker op ingegaan met drie blokken van uitspraken over de politie, waarbij respondenten weer op een vijfpuntsschaal konden markeren in hoeverre zij het daarmee eens of oneens zijn. Deze drie blokken bevatten uitspraken over het functioneren van de politie in de buurt, zoals 'De politie reageert op problemen in de buurt', de beschikbaarheid van de politie in de buurt, zoals 'Je ziet de politie in de buurt te weinig' en het functioneren van de politie in het algemeen, zoals 'De politie is benaderbaar'. Net als in de vorige onderdelen zijn deze afzonderlijke items gebruikt om tot samengestelde schaalscores te komen met betrekking tot verschillende deelaspecten van het functioneren van de politie. Tabel 2 geeft een overzicht van gebruikte samengestelde schaalscores, de items waaruit deze zijn opgebouwd en de Cronbach's alpha van elke schaalscore. Daaruit blijkt dat alle schaalscores met betrekking tot het functioneren van de politie een voldoende hoge betrouwbaarheid hebben: alle Cronbach's $\alpha \geq$.72. Daarom zijn nieuwe samengestelde scores berekend, gebaseerd op het gemiddelde van de samenstellende schalen.

\section{- Overige onderdelen van de vragenlijst}

In de overige onderdelen van de vragenlijst worden achtereenvolgens vragen gesteld over het contact dat respondenten hebben gehad met de politie, hun aangiftegedrag, de informatiebronnen die respondenten raadplegen voor informatie over veiligheid en achtergrondkenmerken van de respondenten, zoals geslacht, leeftijd en etniciteit. Omdat deze onderwerpen niet aan bod komen in het conceptueel model en de data-analyse, worden de betreffende onderdelen van de vragenlijst hier verder niet besproken. 
Tabel 2 Samenstelling schaalscores functioneren van de politie

\begin{tabular}{|c|c|c|}
\hline Schaalscore & Samenstelling & Cronbach's $\alpha$ \\
\hline functioneren van de politie in de buurt & $\begin{array}{l}\text { functioneren politie } \\
\text { buurt, items I t/m } 5\end{array}$ & .92 \\
\hline beschikbaarheid van de politie in de buurt & $\begin{array}{l}\text { beschikbaarheid politie } \\
\text { buurt, items I t/m } 5\end{array}$ & .89 \\
\hline vertrouwen in de politie & $\begin{array}{l}\text { functioneren politie } \\
\text { algemeen, items } 5 \text { en } 9\end{array}$ & .87 \\
\hline politie als crime fighter & $\begin{array}{l}\text { functioneren politie } \\
\text { algemeen, items I en } 8\end{array}$ & .72 \\
\hline wederkerigheid van de relatie met de politie & $\begin{array}{l}\text { functioneren politie } \\
\text { buurt, items } 2 \text { en } 7 ; \\
\text { functioneren politie } \\
\text { algemeen, items } 3 \text { en } 4\end{array}$ & .84 \\
\hline communicatie met de politie & $\begin{array}{l}\text { functioneren politie } \\
\text { algemeen, items } 2,6 \\
\text { en } 7\end{array}$ & .80 \\
\hline
\end{tabular}

\subsection{Participanten vragenlijst}

Om eventuele effecten die worden gevonden in de data toe te kunnen schrijven aan het gebruik van Twitter door de wijkagent, zijn drie groepen respondenten benaderd. Om respondenten te stimuleren de vragenlijst in te vullen en hun adresgegevens op te geven, zijn er onder de deelnemers aan het onderzoek vijf cadeaubonnen verloot.

\section{- Groep 1}

Deze groep bestaat uit burgers in het onderzoeksgebied die één of meer wijkagenten volgen op Twitter. Aan deze burgers is via Twitter gevraagd een online vragenlijst in te vullen op beide meetmomenten. $\mathrm{Zij}$ hebben het verzoek tot deelname ontvangen via de betreffende wijkagenten; deze hebben een bericht met het verzoek tot deelname met daarin een link naar de online vragenlijst geretweet. Daarnaast is het verzoek geretweet door een aantal wijkorganisaties die actief zijn in het onderzoeksgebied en door het algemene twitteraccount van politieregio Midden- en West-Brabant. Ook op de website van de politie Midden- en WestBrabant is een artikel geplaatst over het onderzoek met het verzoek tot deelname en de link naar de vragenlijst; dit is ook opgenomen in het persbericht over de uitbreiding van het aantal twitterende wijkagenten in de regio dat rond dezelfde tijd werd uitgebracht. De verwachting was dat de groep volgers van de wijkagent relatief gemakkelijk te bereiken zou zijn, aangezien het verzoek om de vragenlijst in te vullen via Twitter gedaan kan worden, een medium dat deze potentiële respondenten zeker gebruiken. Deze verwachting bleek niet correct: ondanks het grote bereik van de verschillende manieren waarop het deelnameverzoek is uitgezet, bleek het lastig om respondenten bereid te vinden de vragenlijst in te vullen. In meting 1 bevat de groep twittervolgers van de wijkagent 48 respondenten, in meting 2 zijn dat er 24 . Het is niet bekend of respondenten in meting 2 ook hebben deelgenomen aan meting 1 . Gezien de wijze van verspreiding is het lastig een 
indruk te geven van de non-respons: het is niet na te gaan hoeveel burgers het deelnameverzoek bereikt zou kunnen hebben via Twitter en de website van de politie en het is al helemaal niet vast te stellen hoeveel burgers in dit potentiële bereik het verzoek daadwerkelijk hebben gelezen.

\section{- Groep 2}

Deze groep bestaat uit burgers in het onderzoeksgebied die wel gebruikmaken van Twitter, maar geen wijkagent volgen via dit medium. Deze groep is benaderd om een zo zuiver mogelijk beeld te krijgen van de effecten van het gebruik van Twitter door de wijkagent. Wanneer slechts zou zijn gekeken naar respondenten die een wijkagent volgen op Twitter en respondenten die niet actief zijn op Twitter, is het immers de vraag welke factor bepalend is voor eventuele verschillen; het volgen van de wijkagent of het gebruik van Twitter in het algemeen. Om respondenten te stimuleren de vragenlijst in te vullen en hun adresgegevens op te geven, zijn er onder de deelnemers aan het onderzoek vijf Bol.com-cadeaubonnen verloot. Deze groep heeft op dezelfde wijze als groep 1 het verzoek tot deelname aan de vragenlijst ontvangen. In meting 1 bevat deze groep 43 respondenten, in meting 2 zijn dat er 56 . Het is niet bekend of respondenten in meting 2 ook hebben deelgenomen aan meting 1 . Ook bij deze groep is het lastig een indruk te geven van de non-respons, om dezelfde redenen die zijn beschreven bij groep 1 .

\section{- Groep 3}

Deze controlegroep bestaat uit burgers die niet actief zijn op Twitter en dus ook geen wijkagent volgen op Twitter. Zij zijn benaderd via de lokale media, de nieuwsbrief van de wijkraad en de nieuwsbrief van de politie. Daarnaast zijn er vragenlijsten huis-aan-huis verspreid in het onderzoeksgebied. Dit is gebeurd op hetzelfde moment als in groep 1 en 2, zodat de meting in alle groepen over dezelfde periode plaatsvond. De respondenten in deze groep die de vragenlijst aan huis hebben ontvangen, zijn random geselecteerd. In totaal zijn bij het eerste meetmoment 2000 vragenlijsten huis-aan huis verspreid, gelijkelijk verdeeld over de wijken waar de wijkagenten actief zijn. Ook het deelnameverzoek op de website van de politie en in het eerder genoemde persbericht kan deze respondenten hebben bereikt. In totaal hebben in de eerste meting 518 respondenten in deze groep de vragenlijst ingevuld. In de eerste vragenlijst is gevraagd of respondenten mee willen werken aan het vervolg van het onderzoek, zodat zij bij afname van de tweede vragenlijst rechtstreeks benaderd konden worden. Omdat daardoor bij verspreiding van de tweede vragenlijst 164 respondenten rechtstreeks konden worden aangeschreven, is er gekozen voor een beperktere random huis-aan-huisverspreiding in het onderzoeksgebied dan bij de eerste meting: 800 vragenlijsten in plaats van 2000. In de tweede meting hebben in deze groep in totaal 396 respondenten de vragenlijst ingevuld.

Bij beide metingen is het lastig cijfers van non-respons vast te stellen, aangezien een deelnameverzoek de potentiële respondenten op verschillende manieren kan hebben bereikt en niet van elke manier te bepalen is hoeveel burgers het verzoek hebben ontvangen en hoeveel daarvan hebben deelgenomen aan het onderzoek. Daarnaast hadden respondenten in beide metingen de mogelijkheid anoniem deel 
te nemen aan het onderzoek, waardoor ook van de groep respondenten die in de tweede meting rechtstreeks is aangeschreven, niet vast te stellen is hoe hoog de respons in die groep was.

\subsection{Analyse van de gegevens}

De analyse van de gegevens verloopt in twee stappen. In eerste instantie zijn de relaties die in het conceptueel model verondersteld worden tussen de verschillende determinanten van veiligheidsbeleving getoetst, zowel voor de eerste meting als voor de tweede meting. Daartoe zijn de verschillende clusters van variabelen onderzocht op basis van de procedure Process (Hayes 2013). Allereerst is de relatie tussen de predictor Oordeel politie en de afhankelijke variabele Veiligheidsbeleving bestudeerd met als mediatoren Inschatting objectieve veiligheid en Risicoperceptie als zogenoemde multiple seriële mediatoren (model 6 in procedure Process). Vervolgens is de relatie tussen Perceptie van leefbaarheid, Risicoperceptie en Veiligheidsbeleving onderzocht (model 4). Tot slot is de relatie tussen Perceptie van sociaal kapitaal en Veiligheidsbeleving onderzocht door middel van een logistische regressieanalyse met Perceptie van sociaal kapitaal als predictor en Veiligheidsbeleving als afhankelijke variabele. Daarbij zijn de reacties van alle informanten geanalyseerd. In die analyse zijn de niet-twitteraars veel zwaarder vertegenwoordigd dan de twitteraars. Omdat we in deze fase van het onderzoek vooral de samenhang tussen de concepten in het model willen onderzoeken, ongeacht de groep waartoe de informanten behoren, is het verschil in groepsgrootte niet relevant voor deze deelvraag.

In tweede instantie is de relatie tussen twittergedrag en de overige variabelen in het conceptuele model onderzocht. Vanwege het geringe aantal respondenten in het onderzoek dat twitterde en een wijkagent volgde, is besloten deze relatie niet te toetsen door middel van een mediatieanalyse, maar door een multivariate variantieanalyse met de verschillende factoren in het conceptueel model als afhankelijke variabele en conditie (twitteraar en volger van wijkagent, twitteraar maar niet-volger, niet-twitteraar) als onafhankelijke variabele en een logistische regressieanalyse met het antwoord op de vraag naar veiligheidsbeleving als afhankelijke variabele en conditie als predictor. Het verschil in omvang van de drie groepen maakt dat de betrouwbaarheidsintervallen voor de gemiddelden van de groepen twitteraars veel groter zijn dan die van de groep niet-twitteraars. Dat is uiteraard van invloed op de power van de toets, maar de statistische analyse houdt daar rekening mee.

\section{Resultaten}

Zoals hierboven beschreven is onze onderzoeksvraag tweeledig. De eerste vraag is of er steun is in de door ons verzamelde data voor het vanuit de literatuur geschetste conceptuele model van de determinanten van veiligheidsbeleving. De tweede vraag is of het gebruik van Twitter van invloed is op die determinanten en op de veiligheidsbeleving. De eerste vraag wordt in paragraaf 5.1 behandeld, de tweede vraag in paragraaf 5.2. 


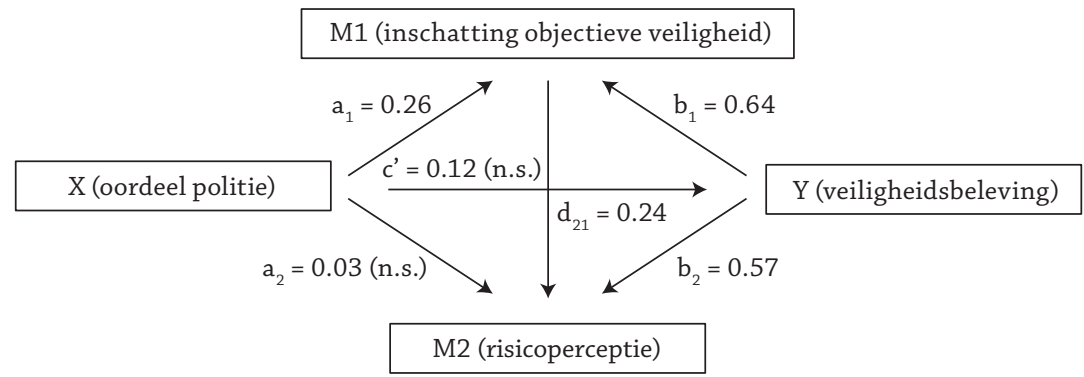

Figuur 2 Mediatieanalyse Oordeel politie, Veiligheidsbeleving met Risicoperceptie en Inschatting objectieve veiligheid als mediators

\subsection{Toetsing conceptueel model}

- De relatie tussen oordeel over politie, inschatting objectieve veiligheid, risicoperceptie en veiligheidsbeleving

Het conceptuele model veronderstelt een seriële mediatierelatie tussen de vier factoren Oordeel over de politie, Inschatting objectieve veiligheid, Risicoperceptie en Veiligheidsbeleving: een positief oordeel over de politie leidt tot een hogere inschatting van de objectieve veiligheid en tot lagere risicoperceptie. Beide leiden op hun beurt tot een hogere veiligheidsbeleving. Deze relaties zijn getoetst op grond van de vragenlijst. Tijdens twee metingen zijn bij grote aantallen respondenten gegevens verzameld volgens de systematiek van de Veiligheidsmonitor. Die antwoorden zijn gebruikt bij de toetsing van het conceptuele model. De details van de statistische analyse zijn te vinden in tabel 1 van de bijlage. De analyse is samengevat in figuur 2.

Het totale directe effect van het Oordeel over politie op Veiligheidsbeleving is niet significant (Coeff=-0.12, $\mathrm{p}=0.11$ ). Wel zijn er indirecte effecten van Oordeel over de politie op Veiligheidsbeleving:

a Het oordeel over de politie heeft een positief effect op de inschatting van de objectieve veiligheid, dat weer een positief effect heeft op de veiligheidsbeleving (Coeff=0.11, $\mathrm{p}<.05$ ): een positiever oordeel over de politie leidt tot een positievere inschatting van de objectieve veiligheid en dat leidt op zijn beurt tot minder onveiligheidsgevoelens.

b Het oordeel over de politie heeft een positief effect op de inschatting van de objectieve veiligheid, dat een positief effect heeft op risicoperceptie, dat op zijn beurt een positief effect heeft op veiligheidsbeleving (Coeff $=0.04, p<.05$ ): een positiever oordeel over de politie leidt tot een positievere inschatting van de objectieve veiligheid, wat tot een lagere risicoperceptie en minder onveiligheidsgevoelens leidt. Het indirecte effect van het oordeel over de politie via risicoperceptie op veiligheidsbeleving is niet significant (Coeff $=0.02$, n.s.). 


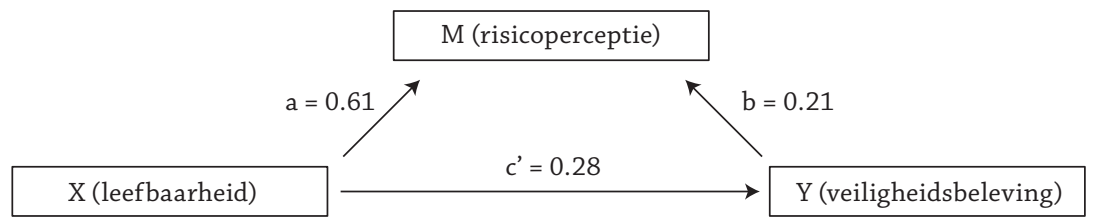

Figuur 3 Mediatieanalyse leefbaarheid, veiligheidsbeleving met risicoperceptie als mediator

- De relatie tussen perceptie van sociaal kapitaal en veiligheidsbeleving

Volgens het model is er een positieve relatie tussen perceptie van sociaal kapitaal en veiligheidsbeleving. Die relatie is getoetst met een logistische regressieanalyse met veiligheidsbeleving als afhankelijke variabele en perceptie van sociaal kapitaal als predictor. De analyse liet zien dat een volledig model significant beter de onveiligheidsreacties voorspelt dan een model met alleen een constante $\left(\chi^{2}(1)=56.43, p<.001\right)$. De Nagelkercke $\mathrm{R}^{2}$ was 0.12 , wat op een zwakke relatie tussen de predictor en de classificatie wijst.

- De relatie tussen perceptie van leefbaarheid, risicoperceptie en veiligheidsbeleving Het conceptueel model veronderstelt een relatie tussen leefbaarheid en veiligheidsbeleving die gemedieerd wordt door risicoperceptie. Om die relatie te toetsen is een mediatieanalyse uitgevoerd, die gerapporteerd wordt in tabel 2 van de bijlage. De analyse is samengevat in figuur 3.

Zowel het directe effect van leefbaarheid op veiligheidsbeleving (Coeff: $0.28, \mathrm{p}<$. 05) als het indirecte effect via risicoperceptie is significant (Coeff: 0.22, p<.05). Dit laat zien dat, in overeenstemming met het conceptuele model, positieve oordelen over leefbaarheid samengaan met verlaagde gevoelens van onveiligheid en dat, eveneens in overeenstemming met het model, verhoogde gevoelens van leefbaarheid samengaan met een lagere risico-inschatting, wat op zijn beurt samengaat met verlaagde gevoelens van onveiligheid.

\subsection{Toetsing van de hypotheses}

Centraal in het onderzoek staat de vraag of er een relatie bestaat tussen het gebruik van Twitter door de wijkagent en de veiligheidsbeleving van de burger. Het conceptuele model veronderstelt dat die relatie gemedieerd wordt door verschillende variabelen. Vanwege de geringe aantallen respondenten die wijkagenten volgen, is besloten deze hypothese niet te toetsen door middel van een mediatieanalyse, maar door een aantal directe regressieanalyses met de verschillende factoren in het conceptueel model als afhankelijke variabele en conditie (twitteraar en volger van wijkagent, twitteraar maar niet-volger, niet-twitteraar) als onafhankelijke variabele. Meting 1 is gebruikt om een schatting te maken van de responsen van de drie groepen respondenten. Allereerst is bezien of er in meting 1 significante verschillen waren tussen de drie groepen respondenten op de varia- 
belen Oordeel over de politie, Sociaal kapitaal, Leefbaarheid, Risicoperceptie en Inschatting objectieve veiligheid. Dat bleek het geval $(F(10,1012)=2.39, p<0.05$, $\eta^{2}=0.02$ ). Bestudering van de univariate verschillen liet zien dat de drie groepen respondenten alleen verschilden op het punt Oordeel over de politie $\left((F 2,509)=3.64, p=0.03, \eta^{2}=0.01\right)$ : het oordeel van de twitteraars die de wijkagent volgen was wat positiever $(\mathrm{M}=4.95)$ dan dat van twitterende niet-volgers $(\mathrm{M}=4.31)$ en niet-twitteraars $(\mathrm{M}=4.32)$.

Gezien de geringe omvang van de verschillen is besloten de oordelen in meting 1 als benchmark te gebruiken om de oordelen in meting 2 tegen af te zetten. Daartoe zijn verschilscores berekend tussen de variabelen in het conceptuele model tussen meting 2 en meting 1 . Die verschilscores zijn vervolgens geanalyseerd als functie van de drie groepen.

Het resultaat van een multivariate analyse met respondentgroep als onafhankelijke variabele en de verschilscores ten opzichte van meting 1 voor Oordeel over de politie, Sociaal kapitaal, Leefbaarheid, Risicoperceptie en Inschatting objectieve veiligheid als afhankelijke variabelen en leeftijd als covariaat liet allereerst zien dat leeftijd geen rol speelde in de analyse $(\mathrm{F}<1)$. Daarnaast bleek het multivariate effect van respondentgroep op de verschilscores significant $(\mathrm{F}(10,798)=$ 2.73, $p<0.01, \eta^{2}=0.03$ ). Bestudering van de univariate effecten liet zien dat de verschillen tussen de respondentgroepen met name van invloed waren op het oordeel over de politie $\left(\mathrm{F}(2,403)=4.08, \mathrm{p}<.05, \eta^{2}=0.02\right)$ en op de inschatting van de objectieve veiligheid $\left(F(2,403)=3.30, p<.05, \eta^{2}=0.02\right)$. De gemiddelde verschilscores staan samengevat in tabel 5 .

Tabel $5 \quad$ Gemiddelde verschilscores tussen meting 2 en meting 1 als functie van respondentgroep (standaarddeviaties tussen haakjes) ${ }^{2}$

\begin{tabular}{llll}
\hline & $\begin{array}{l}\text { Twittert, volgt } \\
(\mathbf{n = 2 4 )}\end{array}$ & $\begin{array}{l}\text { Twittert, volgt niet } \\
(\mathbf{n = 5 4 )}\end{array}$ & $\begin{array}{l}\text { Twittert niet } \\
(\mathbf{n = 3 2 9})\end{array}$ \\
\hline Leefbaarheid & $-0.67(2.0 \mathrm{I})$ & $-0.16(\mathrm{I} .89)$ & $0.05(\mathrm{I} .89)$ \\
Objectieve veiligheid & $-0.38^{\mathrm{a}}(\mathrm{I} .25)$ & $0.4 \mathrm{I}^{\mathrm{b}}(\mathrm{I} .2 \mathrm{I})$ & $0.13^{\mathrm{ab}}(\mathrm{I} .28)$ \\
Oordeel over politie & $1.05^{\mathrm{a}}(\mathrm{I} .63)$ & $-0.03^{\mathrm{b}}(\mathrm{I} .47)$ & $0.10^{\mathrm{b}}(\mathrm{I} .60)$ \\
Risicoperceptie & $0.02(0.86)$ & $0.19(0.83)$ & $0.0 \mathrm{I}(0.78)$ \\
Sociaal kapitaal & $-0.18(2.16)$ & $-0.09(\mathrm{I}) 93)$ & $0.07(\mathrm{I}) \mathrm{75})$ \\
\hline
\end{tabular}

Noot: Gemiddelden met verschillende superscripten verschillen op 5\%-niveau van elkaar.

Paarsgewijze vergelijkingen laten zien dat het verschiloordeel ten opzichte van meting 1 over objectieve veiligheid significant lager is voor de volgende twitteraars (-0.38) dan voor de niet-volgende twitteraars (0.41). Daarentegen oordelen volgende twitteraars significant positiever ten opzichte van meting 1 over de politie (1.05) dan niet-volgende twitteraars (-0.03) en niet-twitteraars (0.10).

2 In de analyse zijn alleen die cases meegenomen die voor elk van de variabelen geen missing values hebben. Daarom kunnen de groottes van de steekproeven van analyse tot analyse verschillen. 
Tabel 6 vat de analyse samen voor de relatie tussen respondentgroep en veiligheidsbeleving.

Tabel 6 Aantal respondenten dat zich wel/niet onveilig voelt, als functie van respondentgroep (percentages tussen haakjes)

\begin{tabular}{llll}
\hline & $\begin{array}{l}\text { Twittert, volgt } \\
(\mathbf{n = 2 4 )}\end{array}$ & $\begin{array}{l}\text { Twittert, volgt niet } \\
(\mathbf{n}=\mathbf{5 6})\end{array}$ & $\begin{array}{l}\text { Twittert niet } \\
(\mathbf{n}=\mathbf{3 7 7})\end{array}$ \\
\hline $\begin{array}{l}\text { Voelt u zich wel eens } \\
\text { onveilig? }\end{array}$ & & \\
Ja & $13(54,2 \%)$ & $20(35,7 \%)$ & $125(33,2 \%)$ \\
Nee & II $(45,8 \%)$ & $36(64,3 \%)$ & $252(66,8 \%)$ \\
\hline
\end{tabular}

De analyse laat zien dat de groep respondenten die wijkagenten op Twitter volgt wat vaker zegt zich onveilig te voelen (twittert, volgt: 54,2\%; twittert, volgt niet: $35,7 \%$; twittert niet: $33,2 \%)$, maar dat het verschil niet significant is $\left(\chi^{2}(2)=4.40\right.$, $\mathrm{p}=0.11$ ).

\section{Conclusies en discussie}

Uit de beschrijving van de aanleiding tot het huidige onderzoek wordt duidelijk dat er nog veel te ontdekken is op het kruispunt van communicatie en criminologie. Omdat communicatie een onderbelicht thema is in de onderzoeken naar de determinanten van veiligheidsbeleving, is het relevant om te onderzoeken of communicatie thuishoort in het rijtje beïnvloedende factoren, zoals met Twitter exemplarisch wordt gedaan in het huidige onderzoek, en zo ja, welke rol communicatie dan precies speelt. Is dit een rechtstreekse invloed op veiligheidsbeleving of een samenhang met andere factoren die de veiligheidsbeleving beïnvloeden?

De processen en factoren die een rol spelen bij het tot stand komen van de veiligheidsbeleving van burgers, zijn voor verschillende beroepsgroepen interessant. Voor de partijen in de veiligheidsketen die zich bezighouden met veiligheid en leefbaarheid (politie, justitie, welzijnsinstellingen, gemeenten) is niet alleen objectieve veiligheid, maar ook subjectieve veiligheid een belangrijk punt. Naast de voor de hand liggende wenselijkheid van het welbevinden van burgers in hun leefomgeving, heeft een positieve veiligheidsbeleving wellicht nog meer voordelen. Te denken valt aan een verhoogde communicatiebereidheid vanuit de burger, die zou kunnen leiden tot een vergroting van de objectieve veiligheid of een positief oordeel over de eigen leefomgeving, wat zou kunnen leiden tot het nemen van verantwoordelijkheid voor de leefbaarheid ervan. Inzicht in welke wijzen van communiceren met de burger een positief effect hebben op de veiligheidsbeleving is daarom voor verschillende maatschappelijke instanties van belang.

Het conceptueel model dat in dit artikel centraal staat, toont verschillende - voor dit onderzoek relevante - determinanten van veiligheidsbeleving en hun onderlinge relaties, zoals die bekend zijn vanuit de literatuur. Aan de hand van een omvangrijke dataset, verworven volgens de systematiek van de Veiligheidsmonitor, zijn deze relaties getoetst. Het conceptueel model wordt ondersteund door 
resultaten van de verschillende analyses: ook in de dataset van het huidige onderzoek worden de verbanden tussen Leefbaarheid, Inschatting objectieve veiligheid, Risicoperceptie, Oordeel over de politie, Sociaal kapitaal en Veiligheidsbeleving gevonden. Daarnaast bleek er een bescheiden maar significant effect van twittergebruik: volgers rapporteren een lagere inschatting van de objectieve veiligheid en een positiever oordeel over de politie dan de andere groepen. Er is geen rechtstreekse, significante relatie gevonden tussen twittergebruik door de wijkagent en veiligheidsbeleving van de burger. Dit laatste kan te maken hebben met de geringe aantallen volgers van de wijkagent in de steekproef. Het kan uiteraard ook betekenen dat er geen relatie is. Aanvullend onderzoek onder meer volgers van wijkagenten is nodig om daar meer duidelijkheid over te verschaffen.

Het onderzoek heeft aangetoond dat communicatie een belangrijke rol kan spelen in de relatie tussen wijkagent en burger. Uiteraard is daarmee nog niet duidelijk wat de mechanismen zijn die in dat proces aan het werk zijn. Daar wordt aandacht aan besteed in een ander deel van het onderzoeksproject waar dit artikel deel van uitmaakt, met behulp van experimenteel onderzoek naar formuleringskeuzes in tweets, inhoudsanalyse van de tweets van succesvolle en minder succesvolle wijkagenten en kwalitatieve interviews met wijkagenten zelf.

\section{Literatuur}

Alford, J. (2009) Engaging public sector clients. From service-delivery to co-production. Houndmills/Basingstoke: Palgrave Macmillan.

Bahn, C. (1974) The reassurance factor in police patrol. Criminology, 12, 338-345.

Balkin, S. en P. Houlden (1983) Reducing fear of crime through occupational presence. Criminal Justice and Behaviour, 10, 13-33.

Blokland, T. (2009) Oog voor elkaar. Veiligheidsbeleving en sociale controle in de grote stad. Amsterdam: Amsterdam University Press.

Boers, J., R. van Steden en H. Boutellier (2008) Het effect van positieve en negatieve factoren op veiligheidsbeleving. Tijdschrift voor Veiligheid, 7(3), 34-52.

Box, S., C. Hale en G. Andrews (1988) Explaining fear of crime. British Journal of Criminology, 28, 340-356.

Brown, G.P. (1980) The Prahan patrol evaluation. Melbourne: Victoria Police Department.

Centraal Bureau voor de Statistiek (2013) Veiligheidsmonitor 2013. Geraadpleegd op www. veiligheidsmonitor.nl.

Cornelissens, A. en H. Ferwerda (2010) Burgerparticipatie in de opsporing: een onderzoek naar de aard, werkwijzen en opbrengsten. Amsterdam: Reed Business.

Crump, J. (2011) What Are the Police Doing on Twitter? Social Media, the Police and the Public Jeremy Crump. Policy\&Internet, 3(4), 1-27.

Directie Veiligheid (2012) Rotterdam Veiligheidsindex 2012. Meting van de veiligheid in Rotterdam. Rotterdam: Gemeente Rotterdam.

Elchardus, M., S. de Groof en W. Smits (2005) Rationele angst of collectieve voorstelling van onbehagen: een vergelijking van twee paradigma's ter verklaring van onveiligheidsgevoelens. Mens en Maatschappij, 80(1), 48-68.

Elffers, H. en W. de Jong (2004) 'Nee, ik voel me nooit onveilig' Determinanten van sociale veiligheidsgevoelens. Nederlands Studiecentrum Criminaliteit en Rechtshandhaving in opdracht van de Raad voor Maatschappelijke Ontwikkeling. 
Ferraro, K.F. (1995) Fear of Crime: Interpreting Victimization Risk. New York: State University of New York Press.

Ferraro, K.F. en R. LaGrange (1987) The measurement of fear of crime. Sociological Inquiry, 57(1), 70-101.

Hale, C. (1996) Fear of crime: A review of the literature. International Review of Victimology, 4, 79-150.

Harris, R. (1969) The Fear of Crime. New York: Praeger.

Hart, J. de (2002) Zekere banden: Sociale cohesie, leefbaarheid en veiligheid. Den Haag: Sociaal en Cultureel Planbureau.

Hayes, A.F. (2013) Introduction to mediation, moderation, and conditional process analysis: A regression-based approach: Guilford Press.

Hunter, A. (1978) Symbols of incivility: social disorder and fear of crime in urban neighborhoods. Paper presented at the Annual Meeting of the American Criminological Society, Dallas.

Jackson, J.P. en B. Bradford (2010) Different Things to Different People? The Meaning and Measurement of Trust and Confidence in Policing Across Diverse Social Groups in London. http://ssrn.com/abstract=1628546 of http://dx.doi.org/10.2139/ssrn. 1628546.

Maas-de Waal, C. (2002) Veiligheid, ontwikkelingen en stand van zaken. In J. de Hart (red.), Zekere banden: Sociale cohesie, leefbaarheid en veiligheid. Den Haag: Sociaal en Cultureel Planbureau.

Meijer, A.J., S. Grimmelikhuijsen, A. Bos en D. Fictorie (2011) Burgernet via Twitter. Onderzoek naar de waarde van dit nieuwe medium. Onderzoek in opdracht van het Programmabureau Burgernet. Utrecht: Universiteit Utrecht.

Meijer, A.J., S. Grimmelikhuijsen, D. Fictorie, M. Thaens en P. Siep (2013) Politie en sociale media. Van hype naar onderbouwde keuzen. Amsterdam: Politie\&Wetenschap/Universiteit Utrecht/Center for Public Innovation.

Newman, O. (1973) Defensible space; crime prevention through urban design. New York: Collier Books.

Oppelaar, J. en K. Wittebrood (2006) Angstige burgers? De determinanten van gevoelens van onveiligheid onderzocht. Den Haag: Sociaal en Cultureel Planbureau.

Ostrom, E. (1996) Crossing the great divide: coproduction, synergy and development. World Development, 24-6, 1073-1087.

Ostrom, E. (1978) Citizen participation and policing: what do we know?. Nonprofit and Voluntary Sector Quarterly, 7-1/2, 102-108.

Pate, A.M., M.A. Wycoff, W.G. Skogan en L.W. Sherman (1986) Reducing Fear of Crime in Houston and Newark: A Summary Report. Washington D.C.: Police Foundation.

Pleysier, S. en G. Vanderveen (2012) Sociale (on)veiligheid kwantificeren: Tussen tellen, meten en weten. In E.R. Muller (red.), Veiligheid en veiligheidsbeleid in Nederland. Deventer: Kluwer, 41-60.

Putnam, R.D. (2000) Bowling alone: The collapse and revival of the American community. New York: Simon and Schuster.

Quinton, P. (2011) The Impact of Information About Crime and Policing on Public Perceptions: NPIA (National Policing Improvement Agency).

Roodenburg, D. en H. Boutellier (2014) Weet wat je tweet. Tijdschrift voor Veiligheid, (13)3, 35-53.

Sampson, R. en S.W. Raudenbush (1999) Systematic social observation of public spaces: A new look at disorder in urban neighborhoods. American Journal of Sociology, 105(3), 603-651. 
Skogan, W.G. en W.R. Klecka (1977) The Fear of Crime (SETUPS: supplementary empirical teaching units in political science). Washington, DC: American political science association.

Sociaal en Cultureel Planbureau (2008) Overgebleven dorpsleven. Sociaal kapitaal op het hedendaagse platteland. Den Haag: Sociaal en Cultureel Planbureau.

Spithoven, R. (2010) Niet bang maar onzeker. Een onderzoek naar overeenkomsten en verschillen in de beleving van sociale onveiligheid in de hedendaagse Nederlandse samenleving. Amsterdam: Vrije Universiteit Amsterdam.

Sztompka, P. (1999) Trust: a sociological theory. Cambridge, UK \& New York, NY: Cambridge University Press.

Taylor, R.B. en M. Hale (1986) Testing alternative models of fear of crime. Journal of Criminal Law and Criminology, 77, 151-189.

Terpstra, J. (2004) Veiligheidszorg en laatmoderniteit: veranderingen in veiligheidsbeleid en zorgen om veiligheid. Beleid en Maatschappij, 31(3), 173-184.

Trojanowicz, R.C. (1986) Evaluating a neighborhood foot patrol program. In D.P. Rosenbaum (Ed.), Community Crime Prevention: Does It Work?. London: Sage.

Van der Vijver, K., P. Geurts en O. Zoomer (2009) De tevredenheid met het laatste politiecontact. Enschede: Politieacademie.

Van Noije, L. en K. Wittebrood (2010) What is fear of crime and how is it determined? A review of the literature. CPSI: Changing perceptions of security and interventions (7th EU framework programme).

Vanderveen, G. (2006) Interpreting fear, crime, risk, and unsafety: conceptualisation and measurement. Den Haag: Boom Juridische uitgevers.

Van Wilsem, J.A. (1997) Slachtofferschap en onveiligheidsgevoelens. In K. Wittebrood, J.A. Michon en M.J. ten Voert (red.), Nederlanders over criminaliteit en rechtshandhaving. Deventer: Gouda Quint, 55-66.

Veltman, L., M. Junger en R. Johannink (2012) Agenten volgen via Twitter bevordert positieve beeldvorming, stimuleert de meldingsbereidheid en verandert de veiligheidsbeleving. Tijdschrift voor Veiligheid, 11(2), 16-29.

Warr, M. (2000) Fear of crime in the United States: Avenues for Research and Policy. In D. Duffee (Ed.), Measurement and Analysis of Crime and Justice. Washington: National Institute of Justice, 451-489.

Wilcox Rountree, P. en K.C. Land (1996) Percieved risk versus Fear of crime: Empirical evidence of conceptually distinct reactions in survey data. Social Forces, 74(4), 1353-1376.

Williams, H. en A.M. Pate (1987) Returning to first principles: Reducing the fear of crime in Newark. Crime and Delinquency, 33, 53-70.

Winkel, F.W. (1986) Reducing fear of crime through police visibility: A field experiment. Criminal Justice Policy Review, 1, 381-398. 
Bijlage

Tabel $1 \quad$ Meting 1 - Samenvatting van de mediatieanalyse met oordeel over de politie als predictor, veiligheidsbeleving als afhankelijke variabele en inschatting objectieve veiligheid en risicoperceptie als seriële mediatoren

\begin{tabular}{|c|c|c|c|c|c|c|c|c|c|c|c|c|}
\hline \multirow[b]{3}{*}{ Antecedent } & \multicolumn{12}{|c|}{ Consequent } \\
\hline & \multicolumn{4}{|c|}{ MI: obj. veiligheid } & \multicolumn{4}{|c|}{$\begin{array}{l}\text { M2: risicopercep- } \\
\text { tie }\end{array}$} & \multicolumn{4}{|c|}{$\begin{array}{l}\text { Y: veiligheidsbele- } \\
\text { ving }\end{array}$} \\
\hline & & Coeff & SE & $p$ & & $\begin{array}{l}\text { Co } \\
\text { eff }\end{array}$ & SE & $\mathbf{p}$ & & $\begin{array}{l}\text { Coef } \\
f\end{array}$ & SE & $p$ \\
\hline $\begin{array}{l}\text { X (oordeel poli- } \\
\text { tie) }\end{array}$ & $a_{1}$ & 0.26 & 0.04 & .000 & $a_{2}$ & 0.03 & 0.02 & .144 & $c^{\prime}$ & 0.12 & 0.07 & .105 \\
\hline $\begin{array}{l}\text { MI (obj. veilig- } \\
\text { heid) }\end{array}$ & & -- & -- & -- & $d_{21}$ & 0.24 & 0.02 & .000 & $b_{1}$ & 0.64 & 0.10 & .000 \\
\hline $\begin{array}{l}\text { M2 (risico-per- } \\
\text { ceptie) }\end{array}$ & & -- & -- & -- & & -- & -- & -- & $b_{2}$ & 0.57 & 0.15 & .000 \\
\hline \multirow[t]{3}{*}{ Constante } & $\mathrm{i}_{\mathrm{MI}}$ & 5.72 & 0.18 & .000 & $\mathrm{i}_{\mathrm{M} 2}$ & 2.17 & 0.16 & .000 & $\mathrm{i}_{Y}$ & -6.12 & 0.77 & .000 \\
\hline & & \multicolumn{3}{|c|}{$R^{2}=0.08$} & & \multicolumn{3}{|c|}{$\mathrm{R}^{2}=0.20$} & & \multicolumn{3}{|c|}{$\begin{array}{l}\text { Nagelkerke } \mathrm{R}^{2}= \\
0.29\end{array}$} \\
\hline & & \multicolumn{3}{|c|}{$F(I, 545)=47.8 I, P=.000$} & & \multicolumn{3}{|c|}{$\begin{array}{l}F(2,544)= \\
66.41, P=.000\end{array}$} & & \multicolumn{3}{|c|}{$-2 L L=|23.5|$} \\
\hline
\end{tabular}

Noot: X: oordeel politie (0..10; 10=positief); veiligheidsbeleving (Y): 0: onveilig; I: niet onveilig; $\mathrm{MI}$ : obj. veiligheid $(0 . .10 ; 10=$ positief); $\mathrm{M} 2$ : risicoperceptie $(0 . .10 ; 10$ is weinig risico).

Tabel 2 Meting 1 -Samenvatting van de mediatieanalyse met perceptie van leefbaarheid als predictor, veiligheidsbeleving als afhankelijke variabele en risicoperceptie als mediator

\begin{tabular}{|c|c|c|c|c|c|c|c|c|}
\hline \multirow[b]{3}{*}{ Antecedent } & \multicolumn{8}{|c|}{ Consequent } \\
\hline & \multicolumn{4}{|c|}{ M: risicoperceptie } & \multicolumn{4}{|c|}{ Y: veiligheidsbeleving } \\
\hline & & Coeff & SE & $p$ & & Coeff & SE & $p$ \\
\hline X (leefbaarheid) & A & 1.09 & 0.02 & .000 & $c^{\prime}$ & 0.28 & 0.11 & .015 \\
\hline $\begin{array}{l}\text { M (risico-percep- } \\
\text { tie) }\end{array}$ & & -- & -- & -- & $b$ & 0.21 & 0.09 & .021 \\
\hline \multirow[t]{3}{*}{ Constante } & $\mathrm{i}_{M}$ & 0.61 & 0.13 & .000 & $\mathrm{i}_{Y}$ & -2.00 & 0.30 & .000 \\
\hline & & \multicolumn{4}{|c|}{$\mathrm{R}^{2}=0.8 \mathrm{I}$} & \multicolumn{3}{|c|}{ Nagelkerke $\mathrm{R}^{2}=0.23$} \\
\hline & & \multicolumn{4}{|c|}{$F(I, 630)=2593.77, p=.000$} & \multicolumn{3}{|c|}{$-2 L L=670.11$} \\
\hline
\end{tabular}

Noot: X: leefbaarheid (0.. 10; I0=positief over leefbaarheid); veiligheidsbeleving (Y): 0: onveilig; I: niet onveilig; M: risicoperceptie (0..10; 10 is weinig risico). 